\title{
WALCZACY Z DEPRESJA. DZIAŁANIA OFENSYWNE ARMII CZERWONEJ NA ŻUŁAWACH WIŚLANYCH W 1945 ROKU
}

\begin{abstract}
Streszczenie. Ofensywa sowiecka z końca marca 1945 r. obejmowała część Żuław Wiślanych - zdobyto wówczas kompleks portowy Gdańska i Gdyni, jednak obrońcy wysadzili w powietrze system przeciwpowodziowy i zalali niektóre obszary delty Wisły, położone w depresji, uniemożliwiając Armii Czerwonej atak od zachodu. Ostatni obrońcy Gdańska wycofali się w rejon odcięty wodą. Po kilku dniach walk prowadzonych w kwietniu, duża część dowodzonej przez generała Iwana Fiediunińskiego 2 Armii Uderzeniowej została przeniesiona w inne obszary, a oddziały Wehrmachtu pozostały w ujściu Wisły i u podstawy Mierzei Wiślanej do ostatniego dnia wojny w Europie.
\end{abstract}

Słowa kluczowe: delta Wisły, tereny depresyjne, ofensywa, zatopienia, Armia Czerwona, 1945

Zuławy Wiślane ${ }^{1}$ są specyficznym regionem geograficznym, który jako jedyny w Polsce położony jest częściowo poniżej poziomu morza. Tereny depresyjne w najniższym punkcie tej krainy osiągają $-1,8 \mathrm{~m}$. W najwyższym miejscu, pod Grabinami, wzniesienie wynosi zaledwie $14,5 \mathrm{~m}$. Granice Żuław wyznaczone są od południa rozwidleniem rzek Wisła i Nogat, na zachodzie i wschodzie miastami Gdańsk oraz Elbląg, od północy natomiast domykają je brzegi Morza Bałtyckiego $^{2}$. Kilkaset lat pracy osadniczej w delcie rzeki Wisły, rozpoczętej

${ }^{1}$ Nazwy geograficzne zostały podane w aktualnym, polskim brzmieniu, a w brzmieniu historycznym w przypisach przy pierwszym wymienieniu. Pominięto brzmienie historyczne nazw ogólnie znanych, jak Żuławy Wiślane, Gdańsk czy Wisła. W przypadku braku polskiego odpowiednika nazwy podano w sposób opisowy, pomagający w lokalizacji.

2 Region dzielony jest zwyczajowo na Żuławy Gdańskie, Malborskie i Elbląskie. Podział przyjęto za: Żutawy Wiślane, red. B. Augustowski, Gdańsk 1976. 
między XII a XIV w., przyniosło osuszenie rozlewisk i utworzenie rolniczo użytkowanych polderów ${ }^{3}$. W średniowieczu stolicę swojego państwa ulokował tu, w Malborku nad rzeką Nogat, Zakon Szpitalny Najświętszej Marii Panny Domu Niemieckiego w Jerozolimie, tzw. Krzyżacy. W 1466 r. ziemie te wcielono do Królestwa Polskiego i w jego granicach pozostały do rozbioru w 1772 r. Później przez półtora stulecia znajdowały się w strukturze państwowej Prus i Niemiec. W międzywojniu znaczną swą częścią współtworzyły obszar Wolnego Miasta Gdańska, a po II wojnie światowej przyznano je Polsce. Zaznaczyć trzeba, że wiodącą rolę w kilkuwiekowym kształtowaniu regionu odegrali przybyli z Niderlandów mennonici, protestanci o surowych zasadach moralnych, dla których ciężka praca była nakazem wiary. Byli to zarazem znakomici specjaliści od osuszania mokradeł i rolniczego zagospodarowywania ziem na tworzonych polderach ${ }^{4}$.

Przedmiotem analiz przedstawionych w poniższym artykule są próby opanowania Żuław Wiślanych przez Armię Czerwoną, ze zbliżeniem na działania w pierwszych dniach kwietnia 1945 r. Za podstawę do badań przyjęto dokumenty źródłowe wojsk, głównie dzienniki działań bojowych. Najważniejszy okazał się dziennik 2 Armii Uderzeniowej (AUd) za kwiecień, będący podsumowaniem sprawozdań jednostek wchodzących w skład armii, jak też dokumenty szczebla korpuśnego i rzadziej dywizyjnego. Niezbędnym wsparciem były mapy sztabowe, prezentujące przebieg walk w założonych cezurach. W oryginałach dokumenty te znajdują się w Centralnym Archiwum Ministerstwa Obrony Federacji Rosyjskiej w Podolsku pod Moskwą. Ich fotokopie, wysokiej jakości, udostępnione są w ramach cyfrowych banków danych. Szczegółowa analiza zdarzeń była możliwa również dzięki stosownej literaturze przedmiotu,

${ }^{3}$ Wybrane przykłady literatury o historii Żuław i mennonitach dostępnej w języku polskim: K. MężYŃski, O mennonitach w Polsce, „Rocznik Gdański” 1960/1961, nr 19/20, s. 185-225; P. Szafran, Żutawy Gdańskie w XVII wieku. Studium z dziejów spotecznych i gospodarczych, Gdańsk 1981; W. DŁUG OKĘCKI, Osadnictwo na Żutawach w XIII i początkach XIV w., Malbork 1992; E. KIZIK, Mennonici w Gdańsku, Elblagu i na Żutawach Wiślanych w drugiej potowie XVII i w XVIII wieku: studium z dziejów matej spoteczności wyznaniowej, Gdańsk 1994; P.J. KLAssen, Ojczyzna dla przybyszów: wprowadzenie do historii mennonitów w Polsce i Prusach, Warszawa 2002; S. KuprJaniuk, Mennonici na Żutawach Malborskich, [w:] Mniejszości narodowe i religijne na Żutawach, red. J. НосHLEITNER, Malbork 2016, s. 39-67.

${ }^{4}$ Oryginalnymi dokumentami życia społecznego są wspomnienia dawnych mieszkańców i gości Żuław. Cf. H. Dyck, Dziennik żutawski, Sztum-Nowy Dwór Gdański 2015; L. Passarge, Z wiślanej delty. Tczew, Gdańsk, Żutawy, Malbork. Szkice z podróży 1856, wyd. J. Borkowıcz, Gdańsk 2016. 
poddanej jednak starannej krytyce z powodu naleciałości ideologicznych z czasów, w których część publikacji powstawałas.

W końcowym stadium II wojny światowej na Żuławach toczono walki od trzeciej dekady stycznia aż do kapitulacji III Rzeszy 8 maja 1945 r. Starciom Armii Czerwonej i Wehrmachtu towarzyszyła masowa ucieczka niemieckich cywilów z zagrożonych terenów, a także zemsta czerwonoarmistów za krzywdy doznane na wschodzie, znaczona na zdobywanych ziemiach gwałtami, grabieżą i pożarami. Okrucieństwo charakteryzowało wówczas obie strony konfliktu i należy zauważyć, że wtedy też przeprowadzona została przez jednostki SS brutalna ewakuacja położonego na skraju regionu żuławskiego obozu koncentracyjnego Stutthof, niosąca tysiącom więźniów śmierć u kresu wojny ${ }^{6}$.

Czerwonoarmiści dotarli na Żuławy Wiślane w niecałe dziesięć dni od rozpoczęcia zimowej operacji ofensywnej 2 Frontu Białoruskiego (FB), ruszającej z wideł Wisły i Narwi 14 stycznia 1945 r. Wykorzystując silne mrozy i zamarzniętą ziemię szybko przenieśli się pod Elbląg i Malbork, rozcinając klinem pozycje niemieckiej 2 Armii (A), dowodzonej przez gen. płk. Waltera Weissa ${ }^{7}$. Sowiecką ofensywę wstrzymało pod koniec stycznia dopiero niebezpieczeństwo przebicia się w tych okolicach, idącej w kontruderzeniu od strony Prus Wschodnich, 4 A gen. piechoty Friedricha Hossbacha ${ }^{8}$, która usiłowała utrzymać korytarze

5 Omawiane zdarzenia zauważały, choć w niezbyt szerokim zakresie, wcześniejsze opracowania: B. Dolata, T. Jurga, Walki zbrojne na ziemiach polskich 1939-1945, Warszawa 1977; Historia II wojny światowej 1939-1945 w 12 tomach, t. 10: Catkowite rozbicie faszystowskich Niemiec, red. polska T. SzaciŁo i inni, Warszawa 1983; E. Kosiarz, Wyzwolenie Polski pótnocnej 1945, Gdynia 1967; K. SовсZак, Kierunek Battyk. Wyzwolenie polskich ziem pótnocnych 1944-1945, Warszawa 1978. W równie niewielkim stopniu tematyka pojawiła się we wspomnieniach sowieckich dowódców, walczących w Gdańsku i okolicach: A. BABADżanian, Drogi zwycięstwa, Warszawa 1974; P. BATow, W marszu i w boju, Warszawa 1963; I. Fiediuniński, Na alarm, Warszawa 1984; K. RokossowsKi, Żotnierski obowiązek, Warszawa 1976; A. WASILEWski, Dzieto catego życia, Warszawa 1976.

${ }^{6}$ Najnowsze badania, głównie związane z cyklem konferencji naukowych „Żuławy w 1945 roku”, reinterpretują dotychczasowy stan wiedzy. Cf. Żutawy w 1945 roku, red. A. GĄsıorowski, J. HoCHLeitner, Sztutowo 2014; Żutawy w 1945 roku. Ludzie i ich opowieści, red. A. GąsiorowsKi, J. Hochleitner, Sztutowo 2015; Żutawy w 1945 roku. Źródta z niedalekiej przesztości, red. A. GĄSiOrowski, J. Hochleit Ner, Sztutowo 2017, s. 15-30; Żutawy w 1945 roku. Niedomknięte księgi, red. T. Gliniecki, M. Owsiński, Sztutowo 2018.

7 Weiss Walter, ur. 1890, generał pułkownik od $1944 \mathrm{r}$. Uczestnik pierwszej wojny światowej. W latach 1943-1945 dowódca 2 A, następnie krótko Grupy Armii „Nord”, w IV 1945 r. przeniesiony do rezerwy kadrowej. W niewoli amerykańskiej był do $1948 \mathrm{r}$. Cf. A. SEATon, Wojna totalna. Wehrmacht przeciw Armii Czerwonej 1941-1945, Kraków 2010, s. 814.

${ }^{8}$ Hossbach Friedrich, ur. 1894, generał piechoty, dowódca 4 Armii. W latach 1934-1938 adiutant wojskowy Hitlera i jego łącznik z armią jako szef centralnego oddziału Sztabu Generalnego. 
transportowe z centralną częścią Niemiec. Niemiecka operacja odblokowania regionu okazała się ostatecznie nieudana, ale zaangażowanie w powstrzymanie tego manewru sił prawego skrzydła $2 \mathrm{FB}$ skutkowało przekazaniem kilku armii w podległość dowódcy $3 \mathrm{FB}$ i zaangażowanie ich w działania daleko na wschód od Żuław'.

Tymczasem Niemcy wycofali swe siły za linię Nogatu i, wykorzystując również nadchodzącą wiosnę, a wraz z nią zmiany pogody oznaczające roztopy, przez kilka miesięcy utrzymywali pozycje obronne w delcie Wisły. Chroniąc się na Żuławach, a także wycofując tędy - szlakiem przez Mierzeję Wiślaną - część wojsk z prowincji wschodniopruskiej, Wehrmacht nadal utrzymywał w okolicach Gdańska silne zgrupowanie wojsk, które potencjalnie zagrażać mogło liniom zaopatrzenia i zapleczu głównego uderzenia sowieckich wojsk, kierujących się w stronę Berlina. Szlaki komunikacyjne na Żuławach posadowione były jedynie na nasypach i koronach wałów, a przez to łatwe do kontrolowania przez obrońców. Próby przełamania oporu wiązały się z dużymi stratami w ludziach i sprzęcie. W dodatku skrajnie ograniczone były tu możliwości ofensywnego wykorzystania czołgów i artylerii samobieżnej. Niemcy zazwyczaj używali swych pojazdów pancernych jako mobilnych punktów artyleryjskich ${ }^{10}$.

Już w marcu 1945 r. spore połacie terenów depresyjnych na Żuławach Wiślanych, szczególnie poldery po wschodniej stronie rzeki, w okolicach Nowego Dworu Gdańskiego, zostały przez Niemców celowo zalane wodą, by powstrzymać siły atakujących. $\mathrm{Na}$ odcięty rozlewiskami obszar wycofało się z końcem miesiąca zgrupowanie broniące Gdańska. Tam połączyło siły z wojskami ocalałymi z likwidowanych kolejno kotłów wschodniopruskich. Znajomość terenu powodowała stałe niebezpieczeństwo kontynuacji działań niemieckich saperów przy niszczeniu nadrzecznych wałów, a wówczas woda rozlać się mogła znacznie szerzej, zatapiając ziemie po granice miasta. Obrona w delcie Wisły angażowała siły kilku sowieckich armii przez następny miesiąc i dopiero majowa kapitulacja

Od VII 1944 do I 1945 r. dowódca 4 A, odwołany przez Hitlera do dyspozycji głównodowodzącego. A. SeATon, op. cit., s. 783-184.

9 T. Chwietkiewicz, Dziatania niemieckiej 4. Armii w Prusach Wschodnich w styczniu i lutym 1945 roku, praca doktorska z 2012 r. w zbiorach Wydziału Nauk Historycznych UMK w Toruniu.

${ }^{10} \mathrm{O}$ walkach niemieckiej 4 DPanc na Pomorzu, w tym na Żuławach i Mierzei Wiślanej, traktują wspomnienia: H. SChäUfler, Pantery nad Wistą. Żotnierze ostatniej godziny, Gdańsk 2010. 
oraz zakończenie wojny w Europie spowodowały całkowite zajęcie terenu Żuław i nasady Mierzei Wiślanej ${ }^{11}$.

Utworzenie przeszkód terenowych poprzez zalanie polderów wodą było jednym z oryginalnych przykładów zastosowania sił natury jako oręża powodującego nagłą zmianę warunków i okoliczności walk ${ }^{12}$.

\section{Pozycje wojsk i układ sił}

Czasem decydującym dla powodzenia walk o Żuławy Wiślane były dni między 1 a 8 kwietnia 1945 r., kiedy jednostki sowieckie próbowały z marszu kontynuować operację wschodniopomorską i, po zdobyciu Gdańska, zmusić przeciwnika do poddania się i złożenia broni. Niemcy jednak nie zamierzali rezygnować z walki, prowadzili też nieprzerwanie operację stopniowej ewakuacji wojsk drogą morską, przez nadal będący w ich rękach port na Helu. Także wcześniej utrzymywali dyscyplinę w szeregach. Wehrmacht otrzymał od dowództwa rozkaz obrony miasta-twierdzy i portu za wszelką cenę, a żołnierzy opuszczających pozycje bez rozkazu karano śmiercią. Dopiero niszcząca siła sowieckiego uderzenia, zwłaszcza potężne bombardowania lotnicze i ogień artyleryjski, wymusiły oddanie miasta atakującym. Przeprowadzone pod koniec marca wycofanie się z bronionych dzielnic w deltę rzeki uchroniło niemieckie jednostki przed ich całkowitą likwidacją. Wisła w dolnym biegu, jej dopływy i liczne mniejsze cieki oraz kanały i rowy melioracyjne przez cały okres walk były kolejnymi, naturalnymi rozgraniczeniami wojsk przeciwników ${ }^{13}$.

${ }_{11}$ T. Gliniecki, Ostatnie walki, negocjacje kapitulacyjne i wzięcie do niewoli jednostek niemieckich z Mierzei Wiślanej w maju 1945 roku, [w:] Kapitulacje w dziejach wojen. Z dziejów wojskowości polskiej ipowszechnej, red. A. Niewiński, Lublin 2017, s. 457-470.

12 Podobną charakterystykę geograficzną miała operacja „Infatuate”, przeprowadzona w 1944 r. w Holandii, kiedy lotnictwo alianckie zbombardowało tamy chroniące depresyjne poldery wyspy Walcheren na Zeelandii. Wody Morza Północnego zalały je tworząc atol i zmuszając wojska niemieckie do obrony przed atakiem sił wysadzonego desantu na wąskich pasach koron wałów. Kapitulacja obrońców pozwoliła odblokować port w Antwerpii. Na podstawie wizyty autora w Polderhuis, Dyke- and war Museum, Westkapelle, NL.

13 Działania jednostek sowieckich na Żuławach Wiślanych w 1945 r., od ofensywy styczniowej po majowe zakończenie wojny, przedstawił autor w książce: T. GLINıECKI, Walki Armii Czerwonej w delcie Wisty (styczeń-maj 1945), Sztutowo-Gdynia 2019. 
Po zdobyciu Gdańska przez Armię Czerwoną, w rozkazie wydanym nocą na 1 kwietnia 1945 r., dowodzący 2 Frontem Białoruskim (FB) marszałek Konstanty Rokossowsk ${ }^{14}$ przekazał podległym oddziałom nowe zadania. 2 Armia Uderzeniowa (AUd), dowodzona przez generała pułkownika I. Fiediunińskiego ${ }^{15}$, otrzymała nakaz likwidacji oddziałów niemieckich, które pod koniec walk opuściły Gdańsk i schroniły się w delcie Wisły. Nie później niż 3 kwietnia armia miała wyjść na lewy brzeg rzeki na odcinku od Steblewa ${ }^{16}$ do Zagrobla pod Płonią Wielką ${ }^{17}$, a kolejnego dnia sforsować nurt i dotrzeć na wybrzeże Zatoki Gdańskiej przy ujściu Wisły Śmiałej ${ }^{18}$. Uderzenie pierwszego rzutu, ze względów technicznych, miało być wsparte batalionami specjalnego przeznaczenia, dysponującymi amerykańskiej produkcji samochodami-amfibiami Ford GPA. Od strony wody wzmocniono siły uderzeniowe kutrami bojowymi Flotylli Dnieprowskiej. Z powodu możliwych, dużych strat w ludziach, jednostki strzeleckie uzupełniono wydzielonymi kompaniami karnymi. Rozwój wydarzeń po kilku dniach spowodował korektę tych poleceń i ofensywę wstrzymano, a znaczna część 2 AUd przeniesiona została rozkazami Stawki Najwyższego Naczelnego Dowództwa na Pomorze Zachodnie. Na sąsiednim odcinku Żuław, obleganym przez lewoskrzydłowe oddziały $3 \mathrm{FB}$, dowódcy 48 Armii (A) generałowi lejtnantowi Nikołajowi Gusiewowi ${ }^{19}$ również zameldowano wtedy, że z powodu

${ }^{14} \mathrm{~W}$ przypisach podane są krótkie biogramy najważniejszych z opisywanych postaci, głównie dowódców z obu stron zmagań. Konstanty Konstantynowicz Rokossowski, ur. 1896, marszałek Związku Sowieckiego, dowodzący 2 FB. Od 1918 r. w RKKA, od 1944 r. marszałek. W latach 1937-1940 stalinowski więzień. Po przywróceniu na stanowisko, jeden z bardziej błyskotliwych dowódców sowieckich. Kolejno dowódca kilku frontów, przed ofensywą styczniową 1945 r. przesunięty przez Stalina z głównego, na wspomagający kierunek uderzenia. Po wojnie był przez kilka lat (1949-1956) ministrem obrony narodowej w Polsce, po czym wrócił do Związku Sowieckiego. A. SeAton, op. cit., s. 803.

15 Fiediuniński Iwan Iwanowicz, ur. 1900, generał pułkownik, dowódca 2 Armii Uderzeniowej. W Armii Czerwonej od 1919 r. W latach 1938-1939 uczestniczył w walkach z Japończykami. Podczas wojny ojczyźnianej 1941-1945 kolejno dowódca kilku armii i zastępca dowódcy kilku frontów. W 1944 r. otrzymał stopień generała pułkownika. Od XI 1943 do V 1945 r., a także przez kilka powojennych lat dowódca 2 AUd; wielokrotnie odznaczany. A. SEATON, op. cit., s. 775.

16 Stüblau.

17 Aussendeich.

${ }^{18}$ Fischereuer Neufähr.

19 Gusiew Nikołaj Iwanowicz, ur. 1897, generał lejtnant, dowódca 48 A. Rosjanin. Członek partii bolszewickiej od 1919 r. Od 1918 r. w Armii Czerwonej na licznych stanowiskach, uczestnik wojny domowej, likwidacji grup białogwardzistów Kołczaka i powstań antykomunistycznych. Licznie na- 
dalszego zatapiania przez Niemców polderów, planowane forsowanie ujścia Nogatu stało się czasowo niemożliwe ${ }^{20}$.

Niemieccy obrońcy od połowy marca kilkakrotnie przeprowadzali częściowe zalania, utrudniające operowanie sowieckich wojsk na Żuławach. Dnia 27 marca osłonili swe pozycje występującymi z brzegów nurtami Wisły Elbląskiej, Linawy Wielkiej, Linawki i Świętej. Do 31 marca woda dosięgła granic Nowego Dworu Gdańskiego $^{21}$, Mirowa ${ }^{22}$, Lubieszewa ${ }^{23}$, Brzózek ${ }^{24}$, Gniazdowa ${ }^{25}$ i wzdłuż wałów wiślanych ku północy. Wody przybywało $2-8 \mathrm{~cm}$ na godzinę, jej średnia głębokość na równinach doszła do $70-150 \mathrm{~cm}$, w depresjach nawet do 3-4,5 m. Niektóre domy i zabudowania gospodarcze zostały zatopione po skraje dachów. Zakładano, że nastąpiło to wskutek zatamowania nurtów Wisły Elbląskiej i Kanału Wiślano-Zalewowego u ich ujścia do Zalewu Wiślanego. Biorąc pod uwagę równinną specyfikę okolic przewidywano dalsze zatopienia i uważano, że stany wód mogą być obniżone jedynie poprzez zniszczenie śluz na zatamowanych ciekach. Niewielkim pocieszeniem było, że rejony zajmowane przez Niemców też zostały częściowo zalane ${ }^{26}$. Łączna linia frontu niemiecko-sowieckiego na styku z 2 AUd wynosiła z początkiem kwietnia $47 \mathrm{~km}$. Przedni skraj obrony przechodził w pierwszych dniach kwietnia prawym brzegiem Wisły od Groblicy $^{27}$ przez Jeziernik ${ }^{28}$, Ostaszewo ${ }^{29}$ do Palczewa ${ }^{30}$. Tam operować miały wówczas niezbyt silne jednostki niemieckie: 491 pułk zapasowy, 315 batalion piechoty morskiej, 5 batalion policyjny i grupa bojowa Blizer o łącznej liczbie

gradzany orderami: Suworowa 1. stopnia, dwukrotnie Czerwonego Sztandaru, Czerwonej Gwiazdy, Znakiem Honoru i Medalem XX lat RKKA. CAMO, fond 33, opis' 686046, jedinica chranienija 40, s. 265-266.

${ }^{20}$ Priedstawiliaju doniesienie komandira 170 SD N $N^{\circ} 25$ od 5.4 .45 so schiemoj rajonow zatoplienija..., CAMO, fond 921, opis' 1, dieło 95, dokumient 191.

21 Tiehenhof.

22 Mirau.

23 Ladekopp.

${ }^{24}$ Bröske.

${ }^{25}$ Schönhorst.

${ }^{26}$ Kratkaja charaktieristika rajona zatoplienija siewiernieje Nojtajch, 1 IV 1945, CAMO, fond 309, opis' 4073 , dieło 762 .

${ }^{27}$ Niederdamm.

${ }^{28}$ Schönsee.

29 Schönberg.

${ }^{30}$ Palschau. 
1600 żołnierzy. Lewym brzegiem linia obronna prowadziła od Steblewa przez Krzywe Koło ${ }^{31}$, Suchy Dąb ${ }^{32}$, Grabiny Duchowne ${ }^{33}$, Rokitnicę ${ }^{34}$, Krępiec ${ }^{35}$, Dobrowo $^{36}$ po Zagroble ${ }^{37}$. Tam obrońców było więcej. W pasie od Steblewa do Krępca sowiecki zwiad wskazał obecność pododdziałów 23 Dywizji Piechoty (DP), 1 i 3 saperskie bataliony zapasowe, 259 batalion ochrony i batalion karny z pułku „Kalthofen”, o łącznej liczbie 2800 ludzi. Na odcinku od Krępca do Martwej Wisły rozpoznano: grupy bojowe 35 i 337 DP; 1113 pułk piechoty (pp) $551 \mathrm{DP}, 1$ batalion 67 pp, 3 batalion 68 pp i 23 zbiorczy pułk 23 DP; 542 DP; 19 i 61 pp 7 DP; 12 DP Luftwaffe, resztki pułków zbiorczych „Danzig” i „Weichsel”, a także pododdziały ze składu 4 DPanc, 503 batalionu czołgów ciężkich i 190 Brygady Dział Szturmowych o łącznej liczbie 10000 żołnierzy. W rejonie Górek Wschodnich ${ }^{38}$ i Sobieszewa ${ }^{39}$ pozycje miały 73 DP oraz grupa bojowa złożona z resztek 389 i 252 DP, w liczbie ponad 4000 ludzi. Łącznie przed frontem 2 AUd działać miało ponad 18000 żołnierzy niemieckich. Zgrupowaniem, które po połączeniu z wojskami przechodzącymi na Mierzeję Wiślaną po utracie Królewca ${ }^{40}$ i Piławy ${ }^{41}$ przemianowano na Armię „Prusy Wschodnie”, dowodził generał wojsk pancernych Dietrich von Saucken ${ }^{42}$. Sowiecka 2 AUd zajmowała 1 kwietnia cały wyznaczony odcinek. Linia o długości 40 km, biegnąca od Steblewa do Krępca, była obsadzona siłami 161 Rejonu Umocnionego (RU). Było to zgrupowanie pomocnicze, składające się z siedmiu wydzielonych batalionów karabinów maszynowych i artylerii (artkaembat) o numerach: 13, 383, 384, 405, 406, 407, 408. Komendantem 161 RU był general major Paweł

31 Kriefkohl.

32 Zugdam.

33 Münchengrebin.

${ }^{34}$ Müggenhahl.

${ }^{35}$ Krampitz.

${ }^{36}$ Neuendorf.

37 Potożienie storon z 1 IV po 3 V 1945 g., CAMO, fond 332, opis' 4948, dieło 401.

38 Östlich Neufähr.

39 Bohnsack.

40 Königsberg, dziś rosyjski Kaliningrad.

41 Pillau, dziś rosyjski Bałtijsk.

${ }^{42}$ Saucken von Dietrich Erich, ur. 1892, generał wojsk pancernych, dowódca 2 Armii, a w ostatnich tygodniach wojny improwizowanej Grupy Armii „Prusy Wschodnie”. Uczestnik pierwszej wojny światowej, później w Reichswehrze. Wysoko odznaczony Krzyżem Rycerskim Krzyża Żelaznego z Liśćmi Dębu, Mieczami i Brylantami, które otrzymał jako 27. niemiecki żołnierz, z ostatnim dniem wojny, 8 V 1945 r. Po wojnie przez dziesięć lat był w niewoli sowieckiej. A. SeAton, op. cit., s. 806. 
Dmitriew $^{43}$. Natomiast siła uderzeniowa 2 AUd, czyli 108, 98 i 116 Korpusy Strzeleckie (KS), skupiała się na wąskim odcinku biegnącym od Krępca do Martwej Wisły, czyli na około $7 \mathrm{~km}$ linii frontu. Odziały armii po marcowych walkach o Gdańsk miały wyjątkowo niskie stany osobowe, zazwyczaj poniżej 3000 żołnierzy na dywizję. Generał Fiediuniński dysponował w dziewięciu dywizjach strzeleckich i rejonie umocnionym łącznie 30000 ludzi ${ }^{44}$.

Rejon zmagań był równiną pociętą gęstą siecią przeszkód wodnych. Tereny depresyjne położone na prawym brzegu Wisły zostały przez Niemców w znacznym stopniu celowo zatopione, co działo się od połowy marca. Na lewym brzegu, na południowy wschód od Gdańska, ziemie też były w sporej mierze polderami leżącymi poniżej poziomu morza i część z nich również uległa zalaniu wodą przez saperów, zazwyczaj poprzez zniszczenie wałów przeciwpowodziowych i urządzeń hydrotechnicznych eksplozjami materiałów wybuchowych. Wiosenne deszcze rozmiękczyły też drogi gruntowe, czyniąc je nieprzejezdnymi dla czołgów, dział samobieżnych i ciężkiego transportu samochodowego. Pojazdy te mogły poruszać się tylko szosami, które były w dobrym stanie technicznym, zarazem jednak obrońcy kontrolowali je ogniem ciężkich karabinów maszynowych oraz artylerii. Dodatkowo Niemcy zaminowywali żuławskie drogi i wysadzali w powietrze mosty, opóźniając posuwanie się czerwonoarmistów. Wehrmacht wykazywał tu silny opór, wykorzystywał sprzyjające warunki terenowe i tworzył wzmocnione punkty obronne. Jednym z takich punktów był Fort Płonia ${ }^{45}$, położony w miejscu, w którym od głównego nurtu rzeki w bok odchodzi Martwa Wisła. Centralna część fortu była obłożona ziemią, która w formie nieregularnego sześciokąta chroniła obiekt z trzech stron. Ziemny wał miał łącznie około $500 \mathrm{~m}$ długości i $4 \mathrm{~m}$ wysokości, a na górze znajdował się dwumetrowy nasyp. Po obu stronach fortu teren był porośnięty krzakami. Na wierzchu przygotowano pojedyncze stanowiska strzeleckie i punkty dla karabinów maszynowych, dokładnie pokrywające ogniem okolicę. Przed wałem ziemnym znajdował się rów z wodą o szerokości $5 \mathrm{~m}$. Część fortu skierowana w stronę Wisły była murowaną ścianą

${ }^{43}$ Dmitriew Paweł Dmitriewicz, ur. 1886, generał major, dowódca 161 Rejonu Umocnionego. W Armii Czerwonej od 1918 r., uczestnik wojny domowej. Od 1926 r. członek partii komunistycznej. Na wojnie ojczyźnianej od VI 1941 r. Odznaczony Orderem Czerwonego Sztandaru, Orderem Wojny Ojczyźnianej 2. stopnia, Medalem XX lat RKKA. CAMO, fond 33, opis’ 686044, jedinica chranienija 118 , s. 4-5.

${ }^{44}$ Zurnat bojewych diejstwij 2 AUd..., s. 451.

${ }^{45}$ Fort Neufähr. 
wysokości 5-6 m. Wewnątrz obiektu znajdowały się dwupiętrowe kazamaty ${ }^{46}$. Załoga fortu liczyła około 200 żołnierzy niemieckich, którzy należeli do 19 pułku z 7 DP, dowodzonej przez generała porucznika Friedrich-Georga von Rapparda ${ }^{47}$. Rankiem 1 kwietnia, od godz. 9.00, oddziały 2 AUd miały rozpocząć atak. $108 \mathrm{KS}$ jedną dywizją ze 1476 pułkiem artylerii samobieżnej (pas) nakazano wyjść na rubież Wocławy-Koszwały ${ }^{48}$ i dalej uderzać w kierunku na Stanisławowo ${ }^{49}$, okolice Trutnowych (nieistniejąca osada) ${ }^{50}$, Straszyn-Pragnszyn $^{51}$, Juszkowo ${ }^{52}$, Rotmanka ${ }^{53} .98 \mathrm{KS}$ z 30 gwardyjskim pułkiem czołgów (gw. pczc), 46 pcz i 1297 pas - otrzymał zadanie zajęcia rubieży od przystanku Koszwały do Bogatki ${ }^{54}$, a następnie wyjścia nad Wisłę pod Kiezmarkiem i Przegaliną 55.116 KS z 59 Brygadą Pancerną (BrPanc) ze składu 8 Korpusu Pancernego Gwardii (KPancGw) oraz 1196 pas miał osiągnąć rubież od Koszwał (nieistniejąca gospoda) ${ }^{56}$ przez Wiślinkę $e^{57}$ po Powiśle ${ }^{58}$ i zająć przeprawę przez Wisłę z możliwością forsowania jej w kierunku Sobieszewa. Główny kierunek ataku armii wyznaczały miejscowości: Płonia Wielka ${ }^{59}$, Wiślinka, okolice Koszwał, Wieniec $^{60}$, Fort Płonia, Wiślińska Łacha ${ }^{61}$. Do wieczora 1 kwietnia nakazano wyprowadzić wszystkie jednostki, w tym uzupełnienia i tyły, z zajętych w ostatnich dniach dzielnic Gdańska i jego przedmieść, a na wschód i północ od

46 Zurnat bojewych diejstwij 2 AUd..., s. 452.

${ }^{47}$ Rappard von Friedrich-Georg, ur. 1892, generał porucznik, dowódca 7 DP. Patent oficerski uzyskał przed I wojną światową. 1 XI 1942 r. objął dowodzenie „bawarską” 7 Dywizją Piechoty i dotrwał z nią do końca wojny, kiedy jednostki jego grupy bojowej skapitulowały w rejonie ujścia Wisły 9 V 1945 r. Trafił z Żuław do niewoli sowieckiej. Po procesie o zbrodnie wojenne został publicznie powieszony w 1946 r. http://www.lexikon-der-wehrmacht.de/Personenregister/R/RappardFGv.htm [dostęp: 18 IV 2018].

${ }^{48}$ Gottswalde.

49 Schönau bei Herzberg.

50 Trutenauer Herrenland.

${ }^{51}$ Prangschein.

52 Gischkau.

53 Rottmansdorf.

${ }_{54}$ Reichenberg.

55 Einlage.

56 Scheer Krug.

57 Wesslinken.

58 Bohnsackertroyl.

59 Gross Plehnendorf.

${ }^{60}$ Siegeskranz - prawdopodobnie część wsi Kronenhof.

${ }^{61}$ Wesslinker Aussendeich. 
rubieży Rotmanka-Borkowo ${ }^{62}$-Kowale zabroniono rozmieszczania jakichkolwiek jednostek bojowych. $8 \mathrm{KPancGw}$, bez 59 BrPanc, miał przejść w rejon Kowale, Bąkowo ${ }^{63}$, Jankowo Gdańskie ${ }^{64}$ i zgrupować tam swe siły, nadwątlone marcowymi starciami ${ }^{65}$. Przyparci do wybrzeża Zatoki Gdańskiej Niemcy nasilili obronę. Z północnego brzegu Martwej Wisły, okolic Krakowca ${ }^{66}$ i lasu na północny wschód od niego prowadzili silny ogień flankujący z dziewięciu baterii i pięciu pojedynczych dział, sześciu pojedynczych i ośmiu baterii moździerzy, a także pięciu stanowisk moździerzy sześciolufowych. Intensywnie ostrzeliwano rejon przeprawy przez strugę Czarna Łacha ${ }^{67}$. Ogień na sowieckie pozycje prowadziła też artyleria okrętów Kriegsmarine z wód zatoki, a obserwatorzy kierowali jej baterie na cele naziemne. Czerwonoarmiści szukali sposobu przeciwdziałania ostrzałowi z morza, ale nie znaleźli skutecznego rozwiązania ${ }^{68}$.

\section{1 kwietnia $1945 \mathrm{r}$.}

O godz. 9.00 jednostki 2 AUd podjęły atak, sforsowały Czarną Łachę i do wieczora stanęły na wskazanych rubieżach. 46 DS ze $108 \mathrm{KS}$ walczyła o Dobrowo i okoliczne kolonie domów, 1238 pp 372 DS chronił prawe skrzydło korpusu na odcinku Olszynka Mała ${ }^{69}$-Olszynka Wielka, a 1236 i 1240 pp były zgrupowane w Straszynie; 90 DS była w rejonie Rotmanki. 281 DS z 98 KS oraz 95 pcz walczyły o przystanek Dobrowo, 946 pp 142 DS, wspierany ogniem 94 pcz, przeprawił się przez Czarną Łachę i wyszedł na rubież $200 \mathrm{~m}$ na wschód i północny wschód od punktu wysokościowego 0.0; 326 DS z 1196 pas prowadziła bój na rubieży punkt 0.7 o $500 \mathrm{~m}$ na zachód od Zagrobla. Artyleria 2 AUd zabezpieczała działania jednostek strzeleckich, organizowała punkty wsparcia ataku, ogniem kontrbateryjnym zmuszała do milczenia niemieckie działa. Tej

\footnotetext{
62 Borgfeld.

63 Bankau.

64 Jenkau.

${ }^{65}$ Zurnat bojewych diejstwij 2 AUd..., s. 453.

66 Krakau.

67 Schwarze Lake.

68 Po imiejuszczimsia razwieddannym $w$ portach Danzig $i$ Gdynia nachodiatsa korabli, 22 III 1945, CAMO, fond 3407, opis' 1, dieło 198, s. 39.

69 Klein Walddorf.
} 
doby każda ze stron wystrzeliła ponad 10000 pocisków. Wojska inżynieryjne armii rozminowywały zdobyty Gdańsk, udrażniały trasy przemarszu i prowadziły rozpoznanie przeszkód wodnych. Zwiadowcy donieśli, że mosty na Czarnej Łasze zostały przez wroga wysadzone w powietrze.

W rejonie Martwej Wisły jednostki sowieckie rozszerzyły stan posiadania o $500 \mathrm{~m}$ do $1 \mathrm{~km}$ na południowym brzegu, ale stało się to za cenę sporych strat własnych. 1 kwietnia wyniosły one 584 zabitych i rannych, w tym w dywizjach: 46 DS - 175, 281 DS - 54, 142 DS - 128, 321 DS - 71, 326 DS - 143 żołnierzy. Bójz Niemcami cofającymi się w kierunku północno-wschodnim, na Sobieszewo i Górki Wschodnie, podtrzymywały wojska $98 \mathrm{KS}$, dowodzone przez generała lejtnanta Georgija Anisimowa ${ }^{70}$, ale korpus zaatakował tylko dwoma dywizjami - 281 i 142 DS. W raportach podnoszono, że wojska poruszały się w nieprzyjaznych warunkach terenowych, przeciwnik utworzył dodatkowe przeszkody poprzez zalanie części terenów depresyjnych, a linie oporu miał na brzegach kanałów odwadniających. Atakującym nie sprzyjała też pogoda, ponieważ było dżdżysto, tworzyło się błoto. Przygotowane do działań po zmroku pododdziały 142 DS sforsowały nocą Czarną Łachę, mimo że szerokość nurtu dochodziła do $15 \mathrm{~m}$, a na wschodnim brzegu znajdowały się stanowiska niemieckie. Natomiast 946 pp przeprawił się i zajął przyczółek na drugim brzegu. Z nastaniem dnia pułk utracił jednak impet ataku. Do godz. 18.00 oddziały 98 KS raportowały: 1066 pp 281 DS walczył na północny zachód od przystanku Doborowo, 1062 i 1064 pp były w drugim rzucie dywizji; 946 pp 142 DS doszedł na południowo-wschodni skraj bezimiennego przysiółka, a 588 i 461 pp w rejon Reduty Płońskiej ${ }^{11}$, oddziały zaś 381 DS wciąż znajdowały się w Gdańsku w rejonie bastionów przy Opływie Motławy ${ }^{72}$. Atakujący z lewej 116 KS nie sforsował do rana rzeki i dlatego przeciwnik przez cały czas prowadził flankowy ogień na przeprawiony po sąsiedzku 946 pp. Od momentu zajęcia przyczółku przystąpiono tam do stawiania mostu dla artylerii. Zajęli się tym specjaliści z 927 batalionu saperów.

70 Anisimow Gieorgij Iwanowicz, generał lejtnant, dowódca 98 Korpusu Strzeleckiego. Urodzony w 1897 r. Rosjanin. Partyjny. Uczestnik wojny domowej w latach 1918-1920. W wojnie ojczyźnianej dowodził dywizjami, a następnie korpusami. Odznaczony orderami: dwukrotnie Czerwonego Sztandaru, Lenina, Suworowa 2. stopnia, Aleksandra Newskiego, medalami za obronę Leningradu i Stalingradu. CAMO, fond 33, opis' 686046, jedinica chranienija 40, s. 475-476.

71 Rückfort.

72 Zurnat bojewych diejstwij 98 sk, 1 IV 1945 - 30 IV 1945, CAMO, fond 991, opis' 1, dieło 245, s. 115 . 
Za dnia most był stawiany trzy razy i za każdym razem Niemcy niszczyli go przy użyciu artylerii. 1 kwietnia został ponownie ustawiony, tym razem pod osłoną ciemności. Na drugą stronę, za pomocą tratw, przerzucono też trzy działa do strzelania na wprost. Dopiero wówczas, pod ich osłoną, most ocalał i przeprawiono po nim artylerię konną 142 pp, a także działa ze 116 KS. Jednak błotniste, nizinne tereny nie pozwalały swobodnie manewrować artylerią, a przy zmianach pozycji żołnierze musieli przenosić działa na plecach, bo nawet konie grzęzły w wiosennym błocie ${ }^{73}$. Na pozycjach oddziałów 161 RU wysokość wody na zalanych polderach podnosiła się o $3 \mathrm{~cm}$ na godzinę i do godz. 18.00 sięgnęła od 1,7 do 2,2 $\mathrm{m}^{74}$. Dowódca 2 AUd rozkazał, by system obrony zreorganizować tu w zależności od stopnia zalania terenu. Tam, gdzie istniało ryzyko zatopienia stanowisk artyleryjskich, nakazano wyprowadzić działa na bezpieczne pozycje. W odciętych wodą miejscach należało przygotować odpowiednio duże zapasy amunicji i wyżywienia, żeby pozostające tam pododdziały mogły prowadzić samodzielną walkę. Polecono zabrać miejscowej ludności wszystkie łodzie i zbudować tratwy, a szef wojsk inżynieryjnych armii miał przekazać 161 RU kuter motorowy i dodatkowe łodzie ${ }^{75}$.

\section{2 kwietnia $1945 \mathrm{r}$.}

Nocą wydano rozkaz dla 161 RU, by 407 artkaembat wycofać z zatopionego rejonu na rubież Marynowy ${ }^{76}$, Mirowo ${ }^{77}, \mathrm{Kącik}^{78} \mathrm{i}$ tam na nowo zorganizować obronę. Na rubieży Lubieszewo ${ }^{79}$, Dziewięć Włók ${ }^{80}$ miały pozostać jedynie posterunki ochronne. Działanie to było utrudnione ze względu na konieczność maskowania manewru. W sztabie $161 \mathrm{RU}$ zanotowano, że wycofanie batalionu było opóźnione z powodu wichru dochodzącego do 10-14 m/s i sztormu, które

\footnotetext{
${ }^{73}$ Dotyczyło to lżejszych dział artylerii pułkowej i dywizyjnej, głównie 45 i $72 \mathrm{~mm}$.

${ }^{74}$ Wypiska iżzurnata bojewych diejstwij czastiej 161 UR, 1 IV 1945 - 30 IV 1945, CAMO, fond 991, opis' 1, dieło 243, s. 1.

75 Zurnat bojewych diejstwij 2 AUd..., s. 453-454.

${ }^{76}$ Marienau.

${ }_{77}$ Mirau.

${ }^{78}$ Neuteicherhinterfeld.

79 Ladekopp.

${ }^{80}$ Neunhuben.
} 
dotknęły zatopionych odcinków Żuław. Zwykłe środki przeprawowe okazały się niestabilne i wywrotne, a działanie kutrów o zanurzeniu $50 \mathrm{~cm}$ było ryzykowne z powodu zalanych nierówności terenu, przegród z drutu kolczastego, czy powalonych pni drzew ${ }^{81}$. Rozpoczęcie ataku głównych sił ustalono na godz. 8.30, nie zmieniając wcześniejszych zadań. Po rozpoczęciu uderzenia Niemcy ostrzelali atakujących z artylerii, w tym 20 pociskami z dział okrętowych. Mimo oporu, 281 DS zajęła przystanek Dobrowo, 321 DS dotarła kilkaset metrów na południe od Płoni Małej" ${ }^{82}$ a 326 DS zdobyła Zagroble. W raporcie armijnym podano, że oddziały przesunęły się do przodu zaledwie o $1 \mathrm{~km}$. Jednostki pancerne i artylerii samobieżnej poruszały się tylko drogami ${ }^{83}$. Artylerzyści armii wystrzelili przez dobę ponad 15000 pocisków. 81 Brygada Artylerii Haubicznej prowadziła ogień do okrętów i barek ewakuacyjnych, zacumowanych na Martwej Wiśle. Straty osobowe Wehrmachtu obliczano na 450 zabitych i rannych. O zaciętości i trudach walk niech świadczy fakt, że straty własne były większe, niż wroga - w całej 2 AUd raportowano ubytek 493 osób, co trzecia służyła w 142 DS. Pochwyceni tego dnia niemieccy jeńcy potwierdzili, że jednostki z pierwszej linii uzupełniane były żołnierzami z rozbitych oddziałów i maruderami, zatrzymywanymi przez patrole żandarmerii i wcielanymi na powrót do naprędce tworzonych grup bojowych ${ }^{84}$. Do godz. 2.00 oddziały $98 \mathrm{KS}$ zajmowały pozycje: 1064 pp 281 DS na wschodnim skraju domów na południe od przystanku Dobrowo, 1062 pp - też tam, tyle że frontem na wschód. 1066 pp bez zgody dowódcy korpusu pozostał w Gdańsku w rejonie Rudno ${ }^{85}$; 946 pp 142 DS był przy moście na strumieniu w ciągu drogi z Koszwał ku północy, 461 pp oczekiwał rozkazów jako wsparcie, 588 pp znajdował się w drugim rzucie; 381 DS nadal nie opuściła Gdańska ${ }^{86}$.

\footnotetext{
${ }^{81}$ Wypiska iż zurnata bojewych diejstwij czastiej 161 UR..., s. 2.

${ }^{82}$ Klein Plehnendorf.

${ }^{83}$ Gross Land.

${ }^{84}$ Zurnat bojewych diejstwij 2 AUd..., s. 457-458.

${ }^{85}$ Część Kneipab.

${ }^{86}$ Żurnat bojewych diejstwij 98 sk..., s. 116.
} 


\section{3 kwietnia 1945 r.}

Straty w ludziach rosły, a sukcesy były nieznaczne, gen. I. Fiediuniński rozkazał więc uporządkować szeregi, dokonać uzupełnień i przeorganizować kompanie, a także szczególowo rozpoznać bieżące cele ataku. W raporcie dziennym podano, że oddziały znów przesunęły się do przodu zaledwie $1-1,5 \mathrm{~km}$. Przyszło też uzupełnienie - 2037 ludzi ze 152 armijnego pułku rezerwowego. Rozdysponowano ich w dywizjach, po około 300-700 osób na każdą. Tym razem działań nocnych nie prowadzono, lecz umacniano się na zajętych terenach. Na niebie pojawiły się niemieckie samoloty - dwie maszyny prowadziły rozpoznanie, a sześć Messerschmittów 109 zaatakowało pozycje 98 i 116 KS. Obrońcy wysadzili w powietrze kolejne wały nadrzeczne, tym razem zatapiając rejon Rokitnicy. Wieczorem raportowano aktualne położenie sowieckich jednostek: 286 pp 90 DS ze $108 \mathrm{KS}$ wraz z 1434 pas uderzał na wschód, zdobywając Rokitnicę; 1238 pp 372 DS atakował ku południu i zajął Krępiec; 314 pp 46 DS wziął domy przy szosie $1 \mathrm{~km}$ na północny zachód od Wocław, 176 i 1476 pp wdarly się do Przejazdowa ${ }^{87}$ i walczyły w centrum wsi. 1259 pp 381 DS ze 98 KS razem z 93 i 94 pcz też walczyły w okolicach Przejazdowa. 281 DS została zmieniona przez oddziały 381 DS i zgrupowana w południowo-wschodniej części Gdańska. 142 DS nie zmieniła pozycji. Oddziały 116 KS wespół z 59 BrPanc odrzuciły dwa kontrataki prowadzone siłą około 200 ludzi i zajęły teren położony 300-500 m na wschód i południowy wschód od Wieńca. Po południu dowódca armii rozkazał 86 DS do godz. 20 przemaszerować przez Pruszcz, Orunię i Gdańsk, do Przeróbki, zwracając szczególną uwagę na dyscyplinę, zwłaszcza przy przejściu żołnierzy ulicami Gdańska. Komendantowi 161 RU nakazano zdjać z linii obronnych dwa bataliony i przekazać je pod dowództwo 86 DS, kierując tą samą drogą do Przeróbki i też zwracając uwagę na odpowiednie zachowanie czerwonoarmistów w mieście. Dotychczasowy odcinek utrzymywać miały trzy bataliony, powiększając rejony odpowiedzialności. 1196 pas został wyprowadzony z walk w rejon Kowali ${ }^{88}$, ponieważ nie dysponował wówczas ani jednym sprawnym działem SU-76. Wojska inżynieryjne przygotowywały się do

\footnotetext{
87 Quadendorf.

88 Kowall.
} 
forsowania Wisły, w związku z tym rekwirowały łodzie okolicznej ludności, co przyniosło łup w postaci 150 jednostek $^{89}$.

$98 \mathrm{KS}$ prowadził działania ofensywne niewielkimi grupami, a walki przybierały coraz gwałtowniejszy charakter. Szturmowcy wdzierali się do kolejnych punktów oporu, zarzucali je granatami, obchodzili, okrążali, czasem powodowali panikę w szeregach wroga i dzięki temu powoli posuwali się do przodu. O godz. 23.00 oddziały raportowały pozycje: 1259 pp 381 DS oczyszczał z wroga Przejazdowo i pobliski przystanek kolejowy, a 946 pp 142 DS, po zajęciu zakładu przemysłowego na południowy wschód od Dobrowa, przeczesywał okolice. Oddziały 281 DS zostały wycofane do drugiego rzutu korpusu ${ }^{90} . \mathrm{Na}$ pozycjach 161 RU, 3 kwietnia o godz. 9.00 żołnierze 405 artkaembat wespół z 1236 pp uderzyli na Rokitnicę (w tym na Hegewaldt, dziś północą część wsi). Po kilku godzinach Niemcy wycofali się na północ i zajęli pozycje na brzegach pobliskiego kanału. W marsz do rejonu zgrupowania w Przeróbce ${ }^{91}$ ruszył 384 artkaembat, który oddano pod rozkazy $98 \mathrm{KS}$, a 407 artkaembat nakazano zająć nowe pozycje na linii Marynowy-Mirowo-Kącik ${ }^{92}$.

\section{4 kwietnia $1945 \mathrm{r}$.}

Rozkaz dzienny gen. I. Fiediunińskiego wyznaczył początek ataku na godz. 11.00. W ciągu dnia 381 DS $98 \mathrm{KS}$ zajęła Wocławy, 142 DS prowadziła boje pod Bogatką, 281 DS nie raportowała zmian. 321 DS 116 KS zajęła Płonię Wielką i Biały Dom ${ }^{93}$, 326 DS zdobyła Zagroble i rozpoczęła bój o Fort Płonia, a 86 DS zgrupowano w rejonie Przeróbka, Stogi94. 383 i 384 bataliony 161 RU były w drodze do Przeróbki, a ich odcinki przejęły 13 i 405 atkaembat. Większość jednostek pancernych stanęła w rejonie Przejazdowa, ostrzałem z oddali wspierając dywizje strzeleckie. Wojska inżynieryjne przygotowały osprzęt pod przeprawę promową przez Wisłę. Nadeszły uzupełnienia w liczbie 400 ludzi, lecz podobnie wielu tego dnia armia straciła jako zabitych i rannych.

\footnotetext{
89 Zurnat bojewych diejstwij 2 AUd..., s. 458.

${ }^{90}$ Zurnat bojewych diejstwij 98 sk..., s. 116.

91 Troyl.

${ }^{92}$ Wypiska iż żurnata bojewych diejstwij czastiej 161 UR..., s. 2-3.

93 Weisses Haus.

${ }^{94}$ Heubude.
} 
Znów 2 AUd zdobyła teren na głębokość zaledwie $1 \mathrm{~km}$, tylko przy południowym brzegu Martwej Wisły dochodząc do $2 \mathrm{~km}^{95} .98 \mathrm{KS}$ nadal walczył korzystając z niewielkich grup szturmowych. Nocą 1259 pp oczyścił z wroga Przejazdowo i wyszedł na brzeg kanału przepływającego na południe od wsi ${ }^{96}$. Pierwsza próba forsowania go pododdziałami 1263 pp nie powiodła się, ale o godz. 11.00 atak powtórzono i pułk przeszedł na drugi brzeg, a kontynuując uderzenie, do godz. 16.00 zajął Wocławy ${ }^{97}$ i dotarł na skrzyżowanie dróg na południe od tej miejscowości. Do tego czasu 461 pp, rano wprowadzony do walki, prowadził starcia $500 \mathrm{~m}$ na zachód od przystanku Bogatka. 946 pp był w okolicach punktu 0.1.Z jednostek 161 RU, 383 artkaembat o godz. 17.00 dotarł do Przeróbki, tam też zgrupował się 384 artkaembat, a 407 batalion wyszedł wreszcie z zatopionego rejonu i zajął nową rubież. Bataliony 405, 406 i 408 stały na dotychczasowych pozycjach, 13 batalion zajął odcinek po 383 artkaembat. O godz. $23.30 \mathrm{w}$ rejonie Motławy ${ }^{98}$ zanotowano osiem silnych wybuchów, oznaczających dalsze wysadzanie przez Niemców wałów przeciwpowodziowych ${ }^{99}$.

\section{5 kwietnia 1945 r.}

Tego dnia 46 DS miała przeprawić się przez wodę w rejonie Wocław i uderzać w kierunku wsi Dziewięć Włók, Wiśliny ${ }^{100}$, Grabiny Duchowne. Początek ataku wyznaczono na godz. 10.00. Dwa bataliony z Przeróbki miały zmienić jednostki 65 A na wybrzeżu od Krakowca po molo wschodnie ${ }^{101}$ i do rana 6 kwietnia zorganizować obronę przeciw ewentualnemu desantowi z morza, z przygotowaniem artylerii do działań przeciwokrętowych. Jeszcze w nocy 381 DS zdobyła południową część Przejazdowa i do 6.00 prowadziła bój o Bystrę Wielką ${ }^{102}$, 46 DS próbowała zdobyć Dziewięć Włók, a 281 DS umocniła się w Przejazdowie. Reszta armii nocą nie walczyła. Po rozpoczęciu ataku

\footnotetext{
${ }^{95}$ Zurnat bojewych diejstwij 2 AUd..., s. 451-452.

96 Hoche Forflute.

97 Wotzlaff.

${ }^{98}$ Mittellake.

99 Wypiska iżzurnata bojewych diejstwij czastiej 161 UR ..., s. 3.

100 Hochzeit.

101 Ostmole.

102 Gross Scharfenberg.
} 
dziennego, 46 DS ze 108 KS zajęła Dziewięć Włók, Biały Dwór na wschód od $\mathrm{Krępca}^{103}$, Wiślinę, Lędowo i walczyła o północny skraj Wróblewa ${ }^{104} ; 1238$ pp 372 DS zdobył Krępiec. 381 DS 98 KS, wsparta czołgami 93 pcz i działami 1297 pas, zdobyła Bystrę Wielką, 1066 pp 281 DS walczył na południe od tej miejscowości, natomiast 142 DS wraz z 59 BrPanc zostały powstrzymane silnym ogniem z Fortu Płonia ${ }^{105}$. Rozkaz zdobycia fortu otrzymała też 326 DS ze $108 \mathrm{KS}$. Po południu raportowała ona, że odcinka od dworu $300 \mathrm{~m}$ na południowy wschód od fortyfikacji, po rzekę na północ od niej, broniły pododdziały z 19 i 61 pp 7 DP oraz niewielkie grupki z 24 i 25 pp 12 Dywizji Polowej Luftwaffe. Dysponowały one piętnastoma karabinami maszynowymi, siedmioma działami i baterią moździerzy $81 \mathrm{~mm}$. Podjęte od godz. 10.00 próby opanowania fortu z wykorzystaniem czołgów 59 BrPanc zostały powstrzymane bezpośrednim ostrzałem z niemieckich dział, ale mimo odkrytego terenu, piechocie udało się przesunąć nieco do przodu. Czołgi ostatecznie pozostały przy szosie, skąd wspierały atakujących ogniem z dział. Do godz. $14.00 \mathrm{w}$ dywizji poległo 14 żołnierzy, a 43 zostało rannych ${ }^{106}$. Większość jednostek pancernych została w rezerwie. Podobnie pułki dział samobieżnych - 1195 pas odtwarzał stan materialny, 1476 pas z jednym tylko sprawnym działem SU-76 wycofano do Oruni, 1434 pas pilnował zasadzki pod Rokitnicą. W związku z trudnościami w operowaniu czołgami w terenie grząskim i częściowo zatopionym, dowódca sowieckiej armii rozkazał poruszać się nimi tylko szosami, w grupach po 2-3 maszyny, pozostałe zaś trzymać w ukryciu. 98 KS zezwolono na użycie tylko jednego pułku pancernego z $30 \mathrm{BrPanc}^{107}$.

Tego dnia został wprowadzony do walki 1066 pp 281 DS z zadaniem zajęcia wsi Wocławy. 461 pp, atakujący wzdłuż linii kolejowej, do godz. 10.00 dotarł do przystanku, lecz po kontrataku musiał wycofać się $300 \mathrm{~m}$ na zachód. 946 pp prowadził walki przy punkcie 0.3 i rozpoczął atak na Bogatkę. Uderzenie 1066 pp rozwijało się powoli, koncentrując działania na drogach i zabudowaniach. Atakujące oddziały nie miały możliwości manewrowania siłami nie tylko dlatego, że zatopione odcinki terenu pozwalały atakować jedynie wzdłuż

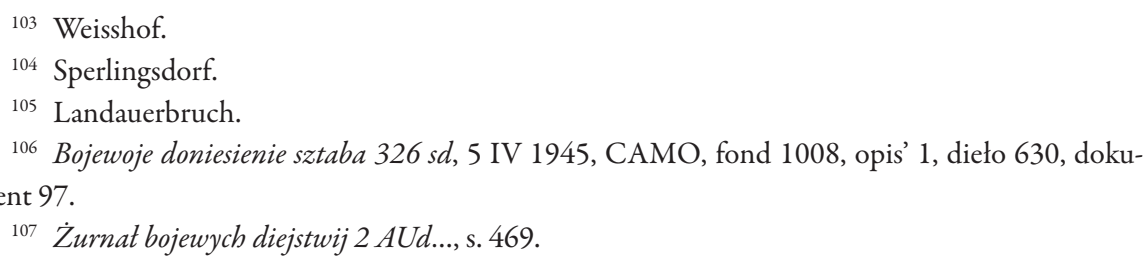


dróg, lecz również z powodu skoncentrowania przez przeciwnika dużej liczby wojska na głównych kierunkach uderzenia. Tego dnia 406 artkaembat zajął dwoma kompaniami Kolonię Lędowo i dotarł do punktu 1.0 $0^{108}$. W kierunku południowo-wschodnim wojska 2 AUd zyskały tego dnia 3-7 km terenu, a na wschodzie sukcesów nie zanotowano. Znacznie zmniejszyła się liczba strat po stronie niemieckiej - podano 290 osób, znów zaś wzrosła po stronie sowieckiej, sięgając 550 zabitych i rannych.

\section{6 kwietnia 1945 r.}

W rozkazie na ten dzień nakazano 46 DS atakować w kierunku miejscowości Grabiny Duchowne, Trutnowy, Cedry Wielkie ${ }^{109}$, a częścią sił iść na Suchy Dąb. 161 RU miał zająć Steblewo i Krzywe Koło. Początek ataku wyznaczono na godz. 11.00. Jeszcze nocą 46 DS zajęła Wróblewo. 1066 pp 281 DS wkroczył do północnej części Wocław i kontynuował atak ku Koszwałom. 1263 pp 381 DS zdobył osadę pod Wocławami ${ }^{110} .383$ i 384 artkaembat przejęły od $105 \mathrm{KS}$ 65 A odcinek wybrzeża od ujścia Wisły do Westerplatte. Niemcy prowadzili ogień artyleryjski z 16 baterii i ośmiu oddzielnych dział, ośmiu baterii moździerzy i trzech wydzielonych, trzech moździerzy sześciolufowych i ciężkiego zestawu miotającego Wurfrahmen 40. W ciągu dnia jednostki 46 DS ze 108 KS dotarły pod Wróblewo, reszta nie notowała zmian położenia. 1066 pp 281 DS z 98 KS podszedł pod Koszwały, a w 381 DS walczył tylko 1263 pp, który powstrzymał niemiecki kontratak. 326 DS kontynuowała bój o Fort Płonia i do walki rzucono trzeci pułk piechoty, starając się rozwinąć atak od strony zachodniej, ale sukcesu nie osiągnięto ${ }^{111}$.

Mimo że na zatopionym terenie, na prawym brzegu Wisły, poziom wód opadł o $25 \mathrm{~cm}$, po lewej stronie rozpoznano nowy rejon zalania na północ od Koszwał. W strategicznie ważnych miejscach czerwonoarmiści umacniali zajęte pozycje. Straty niemieckie tego dnia wyliczono na około 500 ludzi. Sowieckie

\footnotetext{
108 Wypiska iż żurnata bojewych diejstwij czastiej 161 UR..., s. 3.

109 Gross Zünder.

110 Winkel.

${ }_{111}$ Bojewoje doniesienie sztaba 326 sd, 6 IV 1945, CAMO, fond 1008, opis' 1, dieło 630, dokumient 98 .
} 
były wyższe, sięgając 130 zabitych i 551 rannych ${ }^{112}$. Naprzeciw batalionów 161 RU Niemcy bronili się na rubieży: Groblica, Jeziernik, Ostaszewo, ku Wiśle ${ }^{113}$, Suchy Dąb, Grabiny-Zameczek ${ }^{114}$, Grabiny Duchowne, punkty 10.0 i 1.1, Wróblewo. Oprócz dobrze zorganizowanej obrony, podejmowali kontrataki siłą do 120 ludzi, idąc od strony Krzywego Koła. Artyleria wsparcia biła z rejonu Giemlic ${ }^{115}$ i Osic ${ }^{116}$ - około trzech baterii $105 \mathrm{~mm}$, Steblewa - sześciolufowe moździerze, Grabin-Zameczku - bateria moździerzy $120 \mathrm{~mm}$ i Stanisławowa - bateria dział $75 \mathrm{~mm}^{117}$.

\section{7 kwietnia $1945 \mathrm{r}$.}

Nocą na 7 kwietnia nadeszło rozporządzenie sztabu 2 FB nr 00131/OP nakazujące dowódcy 2 AUd pozostawienie do likwidacji wojsk niemieckich w rejonie ujścia Wisły, Ostaszewa, Koszwał i Sobieszewa tylko jednego wzmocnionego korpusu strzeleckiego oraz $161 \mathrm{RU}$, oddając je zarazem pod rozkazy, przejmującego odcinek, dowódcy 5 Armii Pancernej Gwardii (APancGw). Główne siły 2 AUd miały do wieczora 8 kwietnia zgrupować się poza rejonem walk i od rana 9 kwietnia ruszyć w kierunku Szczecina do wskazanych dalej zadań. Dowódca armii wydał zatem szereg rozkazów wyprowadzających jednostki poza strefę walk. $\mathrm{Na}$ ich miejsce nie dano nowych sił, lecz rozciągnięto linie pozostających, więc $98 \mathrm{KS}$ musiał objąć również dotychczasowe pozycje $116 \mathrm{KS}^{118}$. Nocą do rezerw frontowych wycofano też z podległości 2 AUd część artylerii wsparcia i odebrano jej jedną z brygad inżynieryjnych. Zadania dla piechoty natomiast podtrzymano i atak miał ruszyć o godz. 11.00, jednak armia już tylko częścią sił prowadziła działania ofensywne. 46 DS zajęła Grabiny Duchowne, a 381 DS walczyła w centrum Wocław i na linii kolejowej pod Koszwałami. Po raz kolejny straty własne przewyższały straty przeciwnika - przy szacowanych

\footnotetext{
112 Zurnat bojewych diejstwij 2 AUd..., s. 471-572.

113 Osiedle Oberdamm.

114 Herrengrebin.

115 Gemlitz.

116 Wossitz.

117 Wypiska iż zurnata bojewych diejstwij czastiej 161 UR..., s. 4.

118 Zurnat bojewych diejstwij 2 AUd..., s. 475-476.
} 
450 niemieckich zabitych i rannych, po stronie sowieckiej zginęło 165, a raniono 645 ludzi, do tego zaginęły 53 osoby - łącznie zatem sięgnęły 863 żołnierzy. Mimo ponowienia ataku, nie zmieniła się też sytuacja 326 DS pod Fortem Płonia. 1101 pp był na lewym brzegu kanału $250 \mathrm{~m}$ na południe od punktu 1.3, 1097 pp 100 m na południe od fortu, 1099 pp $100 \mathrm{~m}$ na zachód od fortyfikacji. Tu raportowano wyjątkowo wysokie straty w ludziach - zginęło 37, a rannych zostało 108 żołnierzy - co dowodzi wyjątkowo zażartych walk ${ }^{119}$.

406 artkaembat wczesnym popołudniem zajął dwór przy nurcie Kłodawy ${ }^{120}$ i Grabiny Duchowne. W południe część batalionu musiała wraz z oddziałami 46 DS odrzucać trzy kolejne kontrataki niemieckie w rejonie skrzyżowania dróg pod Suchym Dębem. Jednak następnego dnia rano jednostki 161 RU musiały przejąć też pozycje wycofywanej 46 DS w rejonie Wróblewa, co osłabiło sowieckie siły oraz sprowadziło ich aktywność do obrony ${ }^{121}$.

\section{8 kwietnia 1945 r.}

Dowódca 2 AUd nakazał pozostającemu na Żuławach 98 KS kontynuowanie walk, jednak atak miał ruszyć dopiero popołudniem. Korpus tracił wsparcie pancerne w postaci 30 BrPanc i 46 pcz. Tymczasem niemieccy obrońcy zintensyfikowali ogień z dział i moździerzy, próbowali też przeciwuderzenia. Trzy razy - o godz. 6.30, 7.30 i 10.30 - z rejonu wzniesienia 11.0, położonego na północ od Grabin-Zameczku, atakowali pozycje 161 RU, za każdym razem siłą 150 żołnierzy, ale próby te powstrzymano.

W południe $161 \mathrm{RU}$ został oficjalnie podporządkowany dowódcy $98 \mathrm{KS}$, na dotychczasowym odcinku 2 AUd pozostawiono też 1297 pas oraz 230 pułk moździerzy. O godz. 18.00 siły te przekazano pod dowództwo 5 A PancGw. Jednostki $98 \mathrm{KS}$ uzyskały tej doby nieznaczne sukcesy i raportowały pozycje: 1064 pp 281 DS umocnił się w północnej części Wocław po punkt 0.6, 1066 pp

119 Bojewoje doniesienie sztaba 326 sd, 7 IV 1945, CAMO, fond 1008, opis' 1, dieło 630, dokumient 99.

120 Bodenbruch.

121 Wypiska iż zurnata bojewych diejstwij czastiej 161 UR..., s. 5. 
w południowo-wschodniej części Koszwał, 1062 pp w północno-zachodniej części wsi i w kościele; 1261 pp 381 DS zajął północną część miejscowości, 1263 pp stał w zabudowaniach 700 m na południowy wschód od Reduty Płońskiej, 1259 pp w północno-wschodniej części Rudnik ${ }^{122}$; oddziały 142 DS bez zmian.

W podsumowaniu walk 2 AUd za 1-8 kwietnia podano, że linię frontu przesunięto w walkach zaledwie o $4-8 \mathrm{~km}$ na wschód. Niemcy stracili w tych dniach 3420 , a Sowieci 3873 zabitych i rannych ${ }^{123}$. Przewaga strat po stronie atakujących potwierdza duże nasilenie i zawziętość walk w ujściu Wisły, a także skuteczność prowadzenia obrony w celowo zalanym wodą, grząskim i depresyjnym terenie Żuław.

\section{Podsumowanie}

Po kilku dniach prób dalszych walk, podejmowanych lokalnie w okolicach Wocław, na rozkaz dowódcy 5 APancGw, w połowie kwietnia działania ofensywne wstrzymano. Generał Anisimow wydał rozkaz podległym jednostkom: 98 KS i 161 RU, kompanii 18 pułku czołgów, kompanii 14 pułku czołgów ciężkich, 1297 pułkowi artylerii samobieżnej - który wówczas miał sprawne tylko dwa działa - 230 pułkowi moździerzy, 1 dywizjonowi 76 gwardyjskiego pułkowi moździerzy rakietowych „Katiusz” i oddziałowi kutrów Flotylli Dnieprowskiej. Nakazał im bronić osiągniętych pozycji i być w gotowości, by w przypadku cofania się oddziałów niemieckich zajmowały opuszczone przez wroga pozycje. Sowieckie dowództwo nadal obawiało się ewentualności dalszego zatapiania ziem na Żuławach Gdańskich. Wprowadzono więc stałą obserwację stanu wód i urządzeń hydrotechnicznych, wzmocniono ochronę dróg, mostów i punktów przeprawowych. Wskazano rubieże zapasowe w granicach Gdańska i Pruszcza Gdańskiego, na które w razie problemów wycofać się miały pododdziały strzeleckie z pierwszej linii, cała artyleria i wsparcie pancerne $^{124}$.

122 Bürgerwiesen.

123 Zurnat bojewych diejstwij 2 AUd..., s. 481-482.

124 Na stuczaj zatoplienija prikazywaju..., 20 IV 1945, CAMO, fond 332, opis' 4948, dieło 309, dokumient 600 . 
$\mathrm{Z}$ prawej strony korpusu gen. Anisimowa działał $42 \mathrm{KS} 48 \mathrm{~A}$, podległy dowództwu $3 \mathrm{FB}$, a granicą między frontami była linia Półmieście ${ }^{125}$ - Mikoszewo $^{126}$. Z lewej pozycje zajmowały główne siły 5 APancGw, od niedawna dowodzonej przez gen. mjr. Maksyma Sinienkę ${ }^{127}$. Jednostki 98 KS zajmowały teren nadwiślański do początków maja, kiedy odcinek przejęły oddziały $54 \mathrm{KS}$ z 3 A. Krótko po tej zmianie, nocą z 8 na 9 maja 1945 r., z ostatnim dniem wojny w Europie, wojska niemieckie bezwarunkowo skapitulowały. Do kolejnego zalania na Żuławach nie doszło, a oddziały Wehrmachtu broniące się dotąd w delcie Wisły w sposób zorganizowany przeszły do sowieckiej niewoli ${ }^{128}$.

\section{BIBLIOGRAFIA}

\section{Źródła archiwalne}

\section{Centralnyj Archiw Ministierstwa Oborony Rossijskoj Fiedieracyi}

33 - dokumentacja nagrodowa.

309 - 2 Armia Uderzeniowa.

332 - 5 Armia Pancerna Gwardii.

$921-42$ Korpus Strzelecki.

991 - 98 Korpus Strzelecki.

1008 - 326 Dywizja Strzelecka.

3407 - 8 Korpus Pancerny Gwardii.

125 Halbstadt.

126 Nickelswalde.

127 Sinienko Maksim Daniłowicz, ur. 1906, generał major wojsk pancernych, zastępca dowódcy 5 Armii Pancernej Gwardii, od połowy marca 1945 dowodzący nią w miejsce odwołanego gen. Wolskiego. Ukrainiec. Członek partii bolszewickiej od 1920 r. W Armii Czerwonej od 1924 r. Odznaczony czterema Orderami Czerwonego Sztandaru, Orderem Kutuzowa 1. i 2. stopnia oraz medalami Za obronę Moskwy i Za obronę Stalingradu. CAMO, fond 33, opis' 686046, jedinica chranienija 40, s. 301-302.

128 Ot Sowietskogo informbiuro. Opieratiwnaja swodka za $11 \mathrm{~V}$ 1045, „Krasnaja Zwiezda”, $11 \mathrm{~V}$ 1945 , s. 1. 


\section{Prasa}

„Krasnaja Zwiezda” 1945.

\section{Wspomnienia}

Babadżanian A., Drogi zwycięstwa, Warszawa 1974.

Batow P., W marszu i w boju, Warszawa 1963.

Dyck H., Dziennik żutawski, Sztum-Nowy Dwór Gdański 2015.

Fiediuniński I., Na alarm, Warszawa 1984.

Passarge L., Z wiślanej delty. Tczew, Gdańsk, Żutawy, Malbork. Szkice z podróży 1856, Gdańsk 2016.

Rokossowski K., Żotnierski obowiązek, Warszawa 1976.

Schäufler H., Pantery nad Wistą. Żotnierze ostatniej godziny, Gdańsk 2010.

Wasilewski A., Dzieto catego życia, Warszawa 1976.

\section{Opracowania}

Chwietkiewicz T., Dziatania niemieckiej 4. Armii w Prusach Wschodnich w styczniu ilutym 1945 roku, praca doktorska z 2012 r. w zbiorach Wydziału Nauk Historycznych UMK w Toruniu.

Długokęcki W., Osadnictwo na Żutawach w XIII i początkach XIV w., Malbork 1992.

Dolata B., Jurga T., Walki zbrojne na ziemiach polskich 1939-1945, Warszawa 1977.

Gliniecki T., Ostatnie walki, negocjacje kapitulacyjne i wzięcie do niewoli jednostek niemieckich z Mierzei Wiślanej w maju 1945 roku, [w:] Kapitulacje w dziejach wojen. Z dziejów wojskowości polskiej i powszechnej, red. A. Niewiński, Lublin 2017, s. 457-470.

Gliniecki T., Walki Armii Czerwonej w delcie Wisty (styczeń-maj 1945), Sztutowo-Gdynia 2019.

Historia II wojny światowej 1939-1945 w 12 tomach, t. 10: Catkowite rozbicie faszystowskich Niemiec, red. polska T. Szaciło i inni, Warszawa 1983.

Kizik E., Mennonici w Gdańsku, Elblagu i na Żutawach Wiślanych w drugiej potowie XVII i w XVIII wieku: studium z dziejów matej spoteczności wyznaniowej, Gdańsk 1994.

Klassen P.J., Ojczyzna dla przybyszów: wprowadzenie do historii mennonitów w Polsce i Prusach, Warszawa 2002.

Kosiarz E., Wyzwolenie Polski pótnocnej 1945, Gdynia 1967.

Kuprjaniuk S., Mennonici na Żutawach Malborskich, [w:] Mniejszości narodowe i religijne na Żutawach, red. J. Hochleitner, Malbork 2016, s. 39-67. 
Mężyński K., O mennonitach w Polsce, „Rocznik Gdański” 1960/1961, nr 19/20, s. 185-225. Seaton A., Wojna totalna. Wehrmacht przeciw Armii Czerwonej 1941-1945, Kraków 2010.

Sobczak K., Kierunek Battyk. Wyzwolenie polskich ziem pótnocnych 1944-1945, Warszawa 1978.

Szafran P., Żutawy Gdańskie w XVII wieku. Studium z dziejów spotecznych i gospodarczych, Gdańsk 1981.

Żutawy w 1945 roku, red. A. Gąsiorowski, J. Hochleitner, Sztutowo 2014.

Żutawy w 1945 roku. Ludzie i ich opowieści, red. A. Gąsiorowski, J. Hochleitner, Sztutowo 2015.

Żutawy w 1945 roku. Niedomknięte księgi, red. T. Gliniecki, M. Owsiński, Sztutowo 2018.

Żutawy w 1945 roku. Źródta z niedalekiej przesztości, red. A. Gąsiorowski, J. Hochleitner, Sztutowo 2017.

Żutawy Wiślane, red. B. Augustowski, Gdańsk 1976.

\section{Netografia}

www.lexikon-der-wehrmacht.de - biogram Rappard von Friedrich-Georg [dostęp: 18 II 2019].

\section{Tomasz Gliniecki}

\section{FIGHTING WITH DEPRESSION. OFFENSIVE ACTIONS OF THE RED ARMY FOR ZULAWY WISLANE IN 1945}

Summary. The Soviet offensive at the end of March 1945 included part of Zulawy - the port complex of Gdansk and Gdynia was conquered, but then the defenders blew up the flood control system and flooded some of the depression areas, preventing the Red Army from attacking from the West. The last defenders from Gdansk withdrew in the water-cut region. After a few days of fighting in April, a large part of the General I. Fiediuninski's $2^{\text {nd }}$ Shock Army was moved to other areas, and Wehrmacht troops remained in the estuary of the Vistula river and at the base of the Vistula Spit until the last day of the war in Europe.

Keywords: Vistula delta, depressive areas, offensive, flooding, Red Army, war, 1945 